DOI 10.31558/2519-2949.2019.1.13

УДК $327(73+470): 262.81$

ORCID ID: https://orcid.org/0000-0001-6761-3045

Шіхелілі Дюкавід, Київський національний університет імені Тараса Шевченка

\title{
ДО ПИТАННЯ СПІВВІДНОШЕННЯ РЕГІОНАЛЬНОЇ ЕНЕРГЕТИЧНОЇ ПОЛІТИКИ РОСІЇ ТА США У КАСПІЙСЬКОМУ РЕГІОНІ
}

У статті аналізуються ицілі та завдання дипломатії Росії та США в Каспійському регіоні. Автор доводить проблему транзиту у російській та американській енергетичній дипломатії в регіоні, розглядає міждержавні відносини Росії та США із країнами регіону в сфері енергетики. Каспійський регіон став новим иентром тяжіння інтересів держав Заходу і Сходу, він привертає до себе все більшу увагу не лише як регіон-експортер енергоносіїв, а й як важливий транзитний вузол. Саме енергетичний чинник став передумовою політичних, правових і економічних змін в Каспійському регіоні. Ураховуючи геостратегічне положення, політичні, економічні, екологічні та інші чинники Каспійський регіон має важливе значення для Російської Федерації, водночас $i$ в аспекті забезпечення національної безпеки військово-політичного та соціально-економічного характеру. Російська Федерачія намагається відігравати ключову роль в регіоні, враховуючи як енергетичний, так і геополітичний чинники. 3 метою забезпечення власних національних інтересів Росія прагне зберегти свій військово-політичний вплив в регіоні і виключити доступ західних сил на територію Каспію. Значні геополітичні інтереси в Каспійському регіоні мають Сполучені Штати Америки. США намагаються проводити енергетичну політику в иьому регіоні і активно впливати на прочес освоєння енергетичних ресурсів Каспійського моря. 3 иією метою прийнято нову стратегію американської енергетичної політики, яка полягала у витісненні Росії з Каспійського регіону. Цим самим енергетична дипломатія США обумовила створення нової геополітичної ситуачії у відносинах з Росією.

Метою статті с аналіз співвідношення регіональної політики Росії та США у енергетичному вимірі. Констатується, що регіональна стратегія Росії спрямована на політичну ізолячію регіону, успішно реалізовувалась протягом перших десятиліть. Ї̈ методами с творення зон контрольованої нестабільності, затягування територіального розмежування і утворення протиріч у відносинах Каспійських краӥн, військове домінування. Методи дослідження включають геостратегічний аналіз позицї країн регіону у контексті енергетичних иілей політики великих краӥн - США і Російської Федерації. Використовуються методи порівняльного і порівняльно-історичного аналізу, які дозволили визначити передумови формування регіональної політики Росії та США у енергетичному вимірі. Автором зроблений висновок, що, стабільний соціально-економічний розвиток $і$ безпека на півдні Каспійського моря може бути досягнута тільки за умови пошуку механізмів міжнародного співробітництва, результатом якої може стати підписання багатосторонньої угоди щодо міжнародно-правового статусу Каспійського моря.

Ключові слова: енергетична сфера, Каспійський регіон, Каспійське море, міжнародно-правовий статус, прикаспійські держави, регіональна політика.

Вступ. Все більшого значення набуває енергетична сфера. Країни, які володіють енергетичними ресурсами та інфраструктурою їх постачання, здатні реалізувати свої інтереси в межах окремих регіонів і світової політики загалом. Міжнародна співпраця з енергетичних питань потребує забезпечення організаційно-правових засад та механізмів провадження. За таких умов особливу роль починає відігравати енергетична дипломатія, яка забезпечує національні інтереси держави шляхом використання зовнішньополітичних дій, що в свою чергу сприяє формуванню іміджу країни на міжнародній арені, а також є сучасним ефективним механізмом запобігання та подолання викликів, які мають міжнародні наслідки і пов'язані із енергетичними проблемами.

Мета та завдання. Дослідити проблему співвідношення регіональної політики Росії та США у енергетичному вимірі. Розглянути міждержавні відносини Росії та США із країнами Каспійського регіону в сфері енергетики. 
Наукові дослідження. Потрібно відзначити, що в даний час каспійська проблематика достатньо широко представлена в роботах як вітчизняних, так і зарубіжних дослідників, серед яких В. Брушко, А. Джіоєв, А. Дмітрієв, Д. Долгушев, І. Жукова, Д. Зеркалов, В. Салигін, А. Сафарян, С. Черніцина, М. Чумалов, О. Шандро та ін., проте аналіз співвідношення регіональної політики Росії та США у енергетичному вимірі потребує додаткового вивчення.

Методи дослідження. Враховуючи той факт, що Каспій перетворився в один з найважливіших регіонів, де одночасно перетинаються геополітичні, економічні та військово-стратегічні інтереси головних регіональних і світових держав, що відображає складність взаємостосунків між ними, а також ї відносин з численними державними і недержавними акторами на регіональному рівні, в роботі активно використовується суб'єктно-діяльнісний підхід. Даний метод дав можливість виявити і дослідити суперечності між інтересами держав Каспійського регіону, які роблять істотний вплив на регіональну політику Росії та США у енергетичному вимірі. Використані методи порівняльного i порівняльно-історичного аналізу, які дозволили визначити цілі та завдання енергетичної дипломатії Росії та США в Каспійському регіоні, та передумови формування міждержавних відносин Росії та США із країнами в сфері енергетики.

Виклад основного матеріалу.

На сучасному етапі розвитку світової енергетики існує широке коло суб'єктів енергетичної дипломатії:

1) держави-споживачі енергоресурсів;

2) держави-експортери енергоресурсів;

3) міжнародні енергетичні організації;

4) держави, які і споживають, і виробляють енергоресурси;

5) держави-імпортери та експортери, а також держави-транспортери [20, с. 26].

Реалізація енергетичної дипломатії забезпечує вирішення кола таких питань, як: проблеми міжнародного транзиту; суперечності між потенційними країнами-транзитерами енергоресурсів; неврегульованість територіальних (зокрема морських) спорів між країнами щодо суміжних районів, багатих на енергетичну сировину; вирішення інвестиційних проблем i розвитку великих інвестиційних проектів; питання ціноутворення та стабільності енергетичних ринків тощо [8, с. 51-52]. 3 огляду на вищезазначене, ця сфера дипломатії є одним із важливих напрямів зовнішньополітичної діяльності країни, що сприяє створенню умов для нормальних міждержавних відносин в енергетичній сфері.

Після виявлення величезних родовищ нафти і газу Каспійське море стало ареною зіткнення інтересів: по-перше, п'яти прибережних держав (Азербайджан, Іран, Казахстан, Росія, Туркменістан) щодо питання визначення правового статусу моря i способів його подальшого розмежування; по-друге, прикаспійських і сусідніх держав, таких, як Грузія, Іран, РФ, Україна, навколо транспортування сировини; по-трете, найбільших транснаціональних енергетичних корпорацій Свропи, Китаю, Росії, США та інших країн. Каспій перетворився в один 3 найважливіших регіонів, де одночасно перетинаються геополітичні, економічні та військовостратегічні інтереси головних регіональних і світових держав [17, с. 119].

За останні роки енергетичні компанії Росії зміцнили співробітництво зі своїми партнерами в газовому, нафтовому i гідроенергетичному секторах. Все це входить в загальну програму з відновлення російського впливу в Центральноазіатському регіоні, в рамках якої розвиток економічного співробітництва $є$ лише частиною заходів щодо забезпечення гарантій безпеки.

Лідируючі російські позиції в регіоні обумовлені багатьма чинниками, зокрема історикокультурним. Початок контролю над регіоном покладено при царській Росії, згодом СРСР, правонаступницею якого стала сучасна Росія, яка також не здала своїх позицій, - це і послужило створенню досить міцного фундаменту для домінуючого положення РФ в регіоні.

Завдяки своєму геополітичному положенню Росія має вихід до морів як в східному, так і в західному напрямках, що визначає стратегічну важливість іiі положення як транзитної держави.

Росія зацікавлена в збереженні і нарощуванні військового потенціалу, збільшенні економічних ресурсів, необхідних для модернізації армії і вдосконалення військово-промислового комплексу. Для РФ зміцнення своїх позицій на Каспії $\epsilon$ стратегічним напрямом щодо захисту своїх національних інтересів в регіоні і недопущення домінування третіх країн. Для вирішення цих завдань Росії необхідно контролювати дії прибережних держав і пропонувати їм взаємовигідні рішення проблем [26]. 
Геополітичні інтереси Росії в Каспійському регіоні можна визначити як максимальний контроль над транзитом енергетичних ресурсів; збереження своєї присутності в регіоні; недопущення посилення позицій США в регіоні; блокування можливості перетворення Китаю в домінуючу силу в регіоні [6, с. 93].

Енергетична стратегія Російської Федерації спрямована на масштабне залучення в свій паливноенергетичний баланс вуглеводневих ресурсів центральноазіатських країн СНД, включаючи країни Каспійського регіону.

Важливе місце в російській стратегії займає проблема міжнародного-правового статусу Каспійського моря. Позиція Російської Федерації полягає в тому, що Каспійське море є унікальною водоймою, яка не підпадає під дію Конвенції ООН з морського права (1982 р.), тому не може бути поділене на сектори. Росія не визнає будь-яких односторонніх дій щодо Каспію, вважає їх незаконними і залишає за собою право вжити заходів для відновлення порушеного правопорядку та ліквідації наслідків цих дій [5].

3 метою забезпечення власних національних інтересів Росія прагне зберегти свій військовополітичний вплив в регіоні і виключити доступ західних сил на територію Каспію.

Таким чином, на формування стратегії Росії щодо політики в Каспійському регіоні вплинули такі чинники: спроби обмеження доступу третіх країн до Каспійського моря; врегулювання питання правового статусу Каспію; визначення і збереження за собою позиції основної країни-транзитера каспійської сировини на зовнішні ринки тощо. Вищезазначену стратегію можна представити у вигляді декількох основних положень.

По-перше, Росія визнала право кожної прибережної країни Каспію на виняткову юрисдикцію щодо природних ресурсів моря в межах зони шириною 45 морських миль від берега, а також щодо родовищ, які знаходяться за межами цієї зони, але вже розробляються окремою державою.

По-друге, за Росією зберігається контроль над експортними трубопроводами, зокрема через Новоросійськ. Через ії̈ територію проходить нафтопровід «Баку-Грозний-Новоросійськ», пропускна потужність якого складає близько 17 млн. т. нафти на рік. Відтак, це стає основним інструментом контролю над прикаспійськими країнами. Після введення в дію трубопроводів системи КТК, що 3'єднують Західний Казахстан з Новоросійськом, з'явиться магістраль, здатна транспортувати з Каспійської зони на узбережжя Чорного моря до 67 млн. т. нафти. Завдяки таким діям Росія прагне розширення своєї участі в нафтогазовидобувних проектах у Каспійському регіоні (переважно в секторі акваторії, що належить Казахстану). Альтернативою є трубопроводи «Баку-Тбілісі-Супса» i «Баку-Тбілісі-Джейхан» на Чорному морі. Російська Федерація намагається продемонструвати надійність і перспективність російських маршрутів для трубопроводів, що з'єднують Каспій 3 Свропою, а також свою готовність до серйозних компромісів заради реалізації стратегічної мети (спрямувати основний потік нафти через територію Росії).

По-третє, російська влада виступає проти втручання третіх країн у зону Каспію. Знову ж таки з метою збереження свого впливу в регіоні, а також контролю над транзитною системою, яка з'єднує Каспій з основними експортними ринками. Західні країни і закордонні нафтогазові компанії зацікавлені в диверсифікації шляхів поставки енергоносіїв з регіону, зокрема США. Вони підтримують прикаспійські держави шляхом вливання великої кількості інвестиційних ресурсів, що схиляє Азербайджан, Казахстан i Туркменістан до пошуку i будівництва альтернативних трубопровідних систем, в тому числі, що проходять територією Туреччини. Така ситуація пояснюється тим, що інші прикаспійські країни не бажають надавати Росії повний контроль над нафтогазовими потоками регіону.

Російська Федерація, намагаючись зберегти контроль над маршрутами транспортування нафтогазової сировини, шукає ефективні як в політичному, так і в економічному аспекті вигідні шляхи досягнення поставленої мети. Така позиція Росії насторожує інші прикаспійські країни, оскільки транспортна монополія в їх розумінні може призвести до встановлення залежності всіх країн регіону від Росії.

Інші члени прикаспійської п’ятірки зацікавлені в тому, щоб не допустити посилення впливу Росії в регіоні і залучити іноземні інвестиції і капіталовкладення, які необхідні для освоєння родовищ [4].

Значні геополітичні інтереси в Каспійському регіоні мають Сполучені Штати Америки. Починаючи з 1990-х років, США намагаються проводити енергетичну політику в цьому регіоні і активно впливати на процес освоєння енергетичних ресурсів Каспійського моря. 3 цією метою було прийнято нову стратегію американської енергетичної політики, яка полягала у витісненні Росії 
з Каспійського регіону. Енергетична дипломатія США обумовила створення нової геополітичної ситуації у відносинах з Росією.

У 1997-му році США офіційно оголосили Каспійський регіон зоною своїх стратегічних інтересів. Одним з чинників провадження політики США в регіоні стала необхідність захистити економічні інтереси американських нафтових компаній, які уклали в 1993-1994 рр. великі контракти з урядами Азербайджану і Казахстану. Зважаючи на більш оптимістичні експертні оцінки ресурсів Каспію США почали розглядати розробку енергоресурсів Каспію з погляду енергетичної безпеки своєї країни, а також як один з можливих способів диверсифікації джерел світових поставок енергоносіїв [29].

На початку 1998-го року визначено перелік основних завдань американської політики в Каспійському регіоні, до кола яких увійшли такі питання: «Забезпечення безпеки і суверенітету каспійських держав; збільшення i диверсифікація світових джерел енергії; забезпечення регіональної кооперації в цьому регіоні; підтримка нафтових компаній США; чинення тиску на Іран з метою зміни політики цієї держави» [27, 172-173].

Зростаюча увага США до Каспійського регіону пов'язана не лише з наявністю покладів енергетичних ресурсів, але i 3 тим, що тут знаходиться найважливіший перетин світових енергетичних комунікацій за напрямками Північ-Південь, Свропа-Азія. Активність США на Каспії пов'язана з прагненням встановити контроль над розподілом енергетичних ресурсів у світі загалом. Саме це вплинуло на політику США у врегулюванні грузино-абхазького, грузино-осетинського, вірмено-азербайджанського, чеченського та інших конфліктів з метою посилення свого впливу в нових державах. Виходячи 3 нової стратегії американської зовнішньої енергетичної політики основними завданнями США в Центральній Азії є: встановлення контролю над видобутком і транспортуванням нафти і газу з басейну Каспійського моря; створення умов для можливої сировинної блокади Китаю; посилення своєї військової присутності в [32, с. 14].

На думку 3. Бжезинського, каспійська нафта $є$ найкращим інструментом для геоекономічного виведення Середньої Азії і Закавказзя на світові ринки, відірвати їх від Росії і тим самим назавжди ліквідувати можливість пострадянської імперської реінтеграції [1].

У енергетичній політиці США провідну роль відіграють політико-економічні відносини 3 країнами, що володіють великими запасами енергоресурсів на Близькому Сході та в Каспійському регіоні. Першочергово зовнішня політика США в цьому регіоні використовувала кілька ключових інструментів. Одним з яких стало зміцнення політичних і економічних механізмів в прикаспійських державах. Це стосувалося питань щодо побудови демократичної держави, захисту прав людини і формування ринкової системи економіки [23, с. 121]. 3 одного боку, США послідовно виступали проти країн з авторитарними режимами правління, вводячи проти них різні санкції. 3 другого боку, взявши на себе обов'язок щодо реформування державних систем країн Каспійського регіону, США отримали надійний важіль для безпосереднього впливу через «сприяння» в розробці конституцій та інших нормативних актів.

Колишній посол США в Азербайджані Р. Морнінгстар сформулював завдання регіональної політики США. Переважно вона спрямована на зміцнення нових незалежних держав, які йдуть шляхом розвитку ринкової демократії. При цьому США прагнуть розширювати свої комерційні можливості, зміцнювати свою енергетичну незалежність за рахунок каспійських енергоносіїв [16].

27 березня 2012 року під час конференції з обговорення економічної і політичної ситуації в Каспійському регіоні та перспективам його розвитку, яка відбулася у вашингтонському Центрі стратегічних міжнародних досліджень (GSIS), Росс Вілсон, директор Євразійського центру Атлантичної ради США, зазначив, що основою міжнародної дипломатії в Каспійському регіоні служать його енергетичні ресурси, оскільки цей регіон важливий не лише як видобувний, але також і як транзитний канал для транспортування газу і нафти на міжнародний ринок. На думку Росса Вілсона, в останні роки значних змін зазнає політика США в Каспійському регіоні, метою якої є зниження рівня бідності населення в регіоні, підтримка освіти і розвиток економічної самостійності [7].

Як зауважує С. Черніцина, втручання США в справи прикаспійських країн обумовлені виключно політичними і геоекономічними інтересами [24]. По-перше, підтримка діючих урядів Азербайджану i Туркменістану призупиняє можливе поширення ісламського фундаменталізму 3 Ірану. По-друге, розвиток енергетичних секторів цих країн створює альтернативи енергетичної сировини Близького Сходу. По-третє, поширення впливу на регіон безпосередньо послаблює Росію і КНР, основних зовнішньополітичних «суперників» США [11]. 
Таким чином, інтереси США в Каспійському регіоні пов'язані з їх енергетичною стратегією, яка спрямована на диверсифікацію зовнішніх джерел транспортування енергоресурсів, зниження рівня залежності від нестабільного з політичного погляду Близького Сходу, а також забезпечення умов доступу до ресурсів регіону. За таких обставин каспійські інтереси США стають питанням енергетичної безпеки. Враховуючи вигідне геополітичне становище регіону, США прагне зменшити залежність від постачань енергоресурсів з Каспію через територію Росії і розвинути нову транспортну інфраструктуру.

На сьогодні енергетична політика США в Каспійському регіоні передбачає: розширення напрямків і шляхів транспортування енергоносіїв з регіону, використовуючи нафтогазові проекти («Набукко», «Баку-Тбілісі-Ерзерум» та інші); лобіювання Транскаспійських газо- і нафтопроводів; сприяння доступу країн $€$ д до родовищ газу і нафти Каспійського регіону з метою зменшення їх енергетичної залежності від Росії; переорієнтацію економіки і енергоресурсів країн Каспійського регіону на Захід.

Варто зауважити, що одним із важливих завдань США в Каспійському регіоні є розширення міжнародного співробітництва з прикаспійськими країнами, зокрема в аспекті міжнародної безпеки (охорона кордонів, військові навчання НАТО тощо); орієнтація керівництва прикаспійських країн на західні демократичні цінності та європейський енергетичний ринок тощо.

Отже, на сьогодні Каспійський регіон відіграє важливу роль як регіон-експортер енергетичних ресурсів, а також як перетин важливих транспортних комунікацій. Вигідне геополітичне положення перетворює цей регіон у зону стратегічних інтересів багатьох великих світових акторів, зокрема Російської Федерації і Сполучених Штатів Америки. У зв'язку з цим Каспійський регіон залишається для Росії та США пріоритетним напрямом зовнішньої політики.

Енергетична політика США в Каспійському регіоні спрямована на розширення комерційних можливостей для американського бізнесу і ослаблення зв'язків країн регіону з Росією. Водночас енергетична політика США передбачає зниження рівня залежності від постачань енергоресурсів із Близького Сходу, зниження іранського впливу на енергетичний сектор прибережних країн Каспію, а також недопущення появи проектів розробки каспійських родовищ за участю Росії.

Енергетичний чинник геополітичних проблем зони Каспійського басейну обумовлений його розташуванням між азіатськими і європейськими споживачами його ресурсів, які розглядають регіон як зону своїх стратегічних інтересів.

Важливість визначення нових можливих шляхів транспортування пояснюється зацікавленістю не лише прикаспійських держав, а й європейських країн, які потребують диверсифікації поставок енергоносіїв.

Наступний етап передбачає розподіл сфер між країнами-транзитерами. Крім самих прибережних держав у питанні транзиту енергоресурсів зацікавлені Афганістан, Вірменія, Болгарія, Греція, Грузія, Пакистан, Румунія, Туреччина та Україна. Всі ці країни претендують на участь в транспортуванні великих обсягів нафти і газу через свою територію. Основним суперником Російської Федерації в сфері транспортування вуглеводневої сировини в напрямку західного вектора $є$ Туреччина, яка активно підтримується з боку США.

На сьогодні Росія є однією з найбільших країн-експортерів нафти, розташовуючись між трьома світовими ринками: американським, європейським і азіатсько-тихоокеанським, i $\epsilon$ важливою транзитною державою як в східному, так і в західному напрямках. Однак після розпаду СРСР Росія опинилася за межею розроблених морських і континентальних свердловин, оскільки ці родовища розташовані на території сучасного Азербайджану, з їх розвиненою інфраструктурою, терміналами, потужною базою машинобудування, нафтоперегінними заводами і трубопроводами. Росія отримала сектор Північного Каспію, який вважався малодослідженим і проблемним. Поступово транзитний чинник перетворює Каспій з відносно стабільної зони євразійської ресурсної периферії в мінливий геополітичний перетин інтересів багатьох зацікавлених сторін [21, с. 340]. Зокрема, Захід був зацікавлений у зміні транспортної інфраструктури в регіоні і пошуку нових альтернативних шляхів транспортування енергоресурсів.

Вибір шляхів транспортування енергетичних ресурсів з прикаспійських країн на світові ринки став об'єктом гострої конкуренції не тільки між Росією і США, але і між регіональними і позарегіональними країнами - Вірменією, Грузією, Європейським Союзом, Іраном, Туреччиною, Україною, а також великими компаніями. Це пов'язано з тим, що за кожним маршрутом існуючих або проектованих трубопроводів стоять геополітичні та економічні інтереси вищеперерахованих країн, а також комерційні інтереси великих національних компаній. На сучасному етапі 
дипломатична боротьба ведеться за дві групи нафтопроводів - це маршрути транспортування нафти з Казахстану і Росії, а також маршрути транспортування нафти з каспійських родовищ, правовий статус яких ще не визначений.

Надмірна політизація вуглеводневих запасів Каспію зумовила так званий «трубопровідний синдром»- розробку, проектування та будівництво трубопроводів усією територією регіону [21, с. 346]. Крім традиційного трубопроводу «Баку-Новоросійськ», всього за кілька років з'явилися «Баку-Джейхан», «Тенгіз-Новоросійськ», «Баку-Супса» та ін. До сьогодні триває суперництво у розробці та побудові трубопроводів. Для Росії одним з важливих завдань $є$ дипломатичне сприяння в реалізації найбільш вигідних для неї проектів, які передбачають розширення та будівництво Каспійського трубопровідного консорціуму (КТК), трубопроводів «Атирау-Самара», «Бургас-Александруполіс», Прикаспійського газопроводу, модернізацію газопровідної системи «Середня Азія-Центр» (САЦ ), а також «Південний потік». Відтак, Росія залишалася монополістом в сфері транспортування каспійської нафти до 2000-го р., коли Азербайджанська міжнародна операційна компанія (АМОК) ввела в експлуатацію трубопровід для транспортування нафти з Баку в порт Супса на грузинському узбережжі Чорного моря [10].

Після подій в Грузії (серпень 2008-го року) транспортна карта в регіоні змінилася. Росії вдалося деякою мірою посилити відносний контроль над альтернативними трубопроводами, які з'єднують зони Каспію і Чорного моря (нафтопровід «Баку-Супса» і газопровід «Баку-Тбілісі-Ерзурум»).

Це загострило ситуацію в регіоні через перерозподіл сил на користь Росії. Для того, щоб позбутися залежності від російської трубопровідної системи, США лобіювали проект трубопроводу Баку-Тбілісі-Джейхан, який планувався як альтернатива російським та іранським інтересам, навіть незважаючи на величезні фінансові витрати на будівництво. Водночас Сполучені Штати Америки підтримують Туреччину в питанні транспортування нафти в західному напрямку.

Ще однією проблемою в 1990-х роках стало різке зростання цін на нафту за умови пониження кредитних процентних ставок в західних банках.

Оскільки КТК зміцнює позиції Росії в регіоні і на світовому енергетичному ринку, США прагнуть позбутися залежності від російської трубопровідної системи. Адміністрація США більше десяти років активно лобіювала проект нафтопроводу «Баку-Тбілісі-Джейхан» (БТД). Він створювався як альтернатива не тільки російським інтересам, а й іранським, причому останнім навіть більшою мірою. США, за сприяння Азербайджану, Грузії і Туреччини, настільки політизували проект, що, незважаючи на його високу вартість, у 2006-му році відбулося офіційне відкриття нафтопроводу «Баку-Тбілісі-Джейхан» [13].

США прагнуть не допустити монопольного становища будь-якої 3 прикаспійських держав, оскільки це дозволило б диктувати свої умови експортних поставок. Відтак, наполягаючи на реалізації цього Багатовартісного проекту, США бачили в цьому великі переваги для себе. Основна мета будівництва нафтопроводу полягала в створенні незалежного від Росії шляху транспортування нафти з Азербайджану (а згодом і Казахстану) на світові ринки. Окрім цього, США прагнули змінити існуючі нафтові потоки з метою отримання можливості управління в регіоні. Будівництво трубопроводу БТД не лише створює альтернативу російським трубопроводам, але і зміцнює зв'язки між прикаспійськими країнами і Заходом. 3 початком його роботи вкотре істотно змінилася геополітична розстановка сил у регіоні, що охоплює Центральну Азію, Кавказ і акваторію Каспійського моря. Він розглядається як основний експортний трубопровід. Економічні втрати Росії від будівництва нового транспортного шляху каспійської нафти зарубіжні експерти оцінюють в 200 млн. дол. на рік [28].

Як зазначав М. Чумалов, реалізація проекту «Баку-Тбілісі-Джейхан» задовольняє інтереси США, включаючи такі елементи: побудова принципово нового транспортного коридору з Центральної Азії в Свропу; контроль над енергетичними ресурсами регіону, який полегшив США встановлення політичного контролю над пострадянськими країнами. США розраховували тісніше пов'язати свого стратегічного союзника Туреччину з Свропою; перекрити один з можливих джерел енергопостачання Китаю; західний коридор мав забезпечити блокування спроб Ірану прорвати міжнародну ізоляцію [25, с. 207].

В 2007-му році президенти Російської Федерації і Республіки Казахстан Володимир Путін і Нурсултан Назарбаєв досягли домовленості про участь Казахстану в проекті будівництва нафтопровода «Бургас-Александруполіс», спрямованого в обхід Чорного моря з метою зниження транспортування нафти танкерами через протоки Босфор і Дарданелли [14]. Цей нафтопровід альтернатива трубопроводам БТД і Самсун-Джейхан, що проходять турецькою територією. Проте, враховуючи вихід з проекту Болгарії в 2011-му році, цей проект лишився нереалізованим. 
Договір про будівництво газопроводу «Південний потік» підписано під час візиту президента Росії В. Путіна в Софію в січні 2008-го року. Росія планувала постачати газ з Центральної Азії в Європу не через Каспійське море, Іран або Туреччину, а через існуючі комунікації своєю територією, а новим маршрутом російського узбережжя Каспійського моря. Це дозволило б постачати значні обсяги центральноазіатського і російського газу в країни ЄС в обхід держав, які лобіювали американські енергетичні ініціативи (зокрема, Туреччини). Але після анексії Криму Росією Європейський парламент у квітні 2014-го року прийняв резолюцію щодо відмови від будівництва газопроводу «Південний потік». В цьому ж році було демонтовано секцію газопроводу на території Болгарії. На сьогодні відомо, що незабаром проект «Південний потік» знову відновлять, але під назвою «Сербський потік» («South Stream Serbia AG») [15]. Ураховуючи домовленість ПАТ «Газпром» з урядом Туреччини щодо будівництва газопроводу «Турецький потік», «Сербський потік» виступить основним підрядником означеного газопроводу. Таким чином, Росія прагне досягнути поставленої мети - забезпечити постачання газу до країн Європи в обхід території України.

Наразі пріоритетним проектом став Трансадріатичний газопровід (Trans Adriatic Pipeline - TAP). Його будівництво розпочалося у 2016-му році, після схвалення Єврокомісії. Трансадріатичний газопровід має стати частиною Південного газового коридору, який попередньо включав Транскаспійський газопровід із Туркменістану та Азербайджану, а також трубопровід «Набукко» [30].

Російський проект будівництва газопроводу «Блакитний потік» («Blue Stream») залучив до постачання в Туреччину туркменський газ. Постачання до Туреччини розпочалися в 2003-му році. Росія прагнула в подальшому розширити потік до Ізраїлю та Італії, але наразі постачання газу здійснюється лише на територію Туреччини [2]. У травні 2018-го року Росія і Туреччина домовилися про будівництво проекту «Турецький потік», що стане розширенням проекту «Блакитний потік».

Натомість, щоб позбутися залежності від Росії, а також з метою постачання енергоресурсів в західному напрямку 23 грудня 2015-го року Туркменістан запустив газопровід «Схід-Захід» загальною вартістю в 2,5 мільярдів доларів. Його протяжність сягає 800 кілометрів, тягнеться газопровід «Схід-Захід» від родовищ на сході країни до узбережжя Каспійського моря. Це відкриває нові можливості для країни, яка володіє четвертими за обсягами в світі покладами природного газу, i можливо в подальшому після будівництва Транскаспійського трубопроводу туркменський газ постачатимуть в Європу.

США зацікавлені у розширенні енергетичного співробітництва з європейськими країнами, в тому числі з Україною. За таких умов американсько-російські відносини продовжують загострюватися. Так, в червні 2017-го року США розпочали постачання зрідженого природного газу до Польщі. У липні цього ж року президент США Дональд Трамп підписав законопроект, який передбачає введення жорстких санкцій проти Росії. Першочергово це пов'язано з агресивною політикою Росії щодо України (анексія Криму; збройне протистояння на Донбасі в 2014-му році) i має найбільший вплив на економіку Російської Федерації. Метою такого вектора зовнішньої політики США є економічні мотиви, результатом яких, на думку адміністрації Вашингтону, може стати витіснення російської корпорації «Газпром» з європейського ринку, місце якого займуть американські експортери енергоресурсів [19].

Окрім цього, США виступають проти будівництва газопроводу «Північний потік-2» («Nord Stream-2»), який дозволив би Росії постачати газ в Свропу в обхід країн-транзитерів, зокрема i України. Станом на квітень 2018-го року Сврокомісія відмовилася підтримувати будівництво газопроводу «Північний потік-2» [22]. Однією з основних причин такого рішення євродепутатів $є$ те, що на сучасному етапі газопровід «Північний потік-2» не відповідає правилам так званого третього енергетичного пакета $\mathrm{CC}$, оскільки повністю належить «Газпрому».

Уряди Естонії, Латвії, Литви та Польщі виступили зі спільною заявою проти будівництва газопроводу «Північний потік-2». Однак, позитивне рішення щодо будівництва ділянки газопроводу дном Балтійського моря дала німецька влада (земля Мекленбург-Передня Померанія). В разі успішного завершення цього проекту російська корпорація «Газпром» вчергове затвердить свою позицію монополіста на енергетичному ринку і досягне значного впливу в зоні ЄС. США засуджує такі дії Німеччини і попереджує про затвердження санкцій, також адміністрація Вашингтону готує санкції проти країн-учасниць проекту «Північний потік-2» [18].

Однак, Росія прагне позбутися залежності від країн-транзитерів шляхом будівництва трубопроводів в обхід, залишаючи за собою монополію щодо транспортування енергетичних ресурсів Каспію. За умови реалізації російських проектів вплив Росії як країни-експортера та 
країни-транзитера в Європі зросте. Хоча на сьогодні вже розпочато будівництво трубопроводу «Північний потік-2» і погоджено домовленість про будівництво проекту «Турецький потік», можна стверджувати, що враховуючи положення Енергетичної Хартії, це порушуватиме основні принципи міжнародного співробітництва в сфері енергетики і поглиблюватиме залежність європейських країн від енергетичної дипломатії Росії.

Основні тенденції в енергетичній сфері прибережних країн Каспію, а також США можна визначити на основі аналізу статистичних результатів вивчення енергетичної архітектури (energy architecture), яку розглядають як систему, що містить такі компоненти: енергетичні ресурси; постачання; формування попиту на енергетичні ресурси (діяльність уряду, промисловості та суспільства) [31]. Наразі найбільші постачальники світової енергії продовжують боротьбу за лідерські позиції в рейтингу за Індексом функціональності енергетичної архітектури (ЕАРI) на світовому енергетичному ринку. Станом на 2017-й рік Російська Федерація посідає 48 місце в рейтингу, а США - 52 місце. В 2009-му році Росія займала 33 місце в рейтингу, а США - 54 місце. Порівняно з показниками 2014-го року в 2017-му році РФ посіла нижчу позицію в рейтингу (за даними The Global Energy Architecture Performance Index Report 2014, 28 і 37 місця відповідно) [46]. Таким чином, можна стверджувати, що в останні роки існує негативна динаміка i втрата лідерських позицій Росії та США в рейтингу за Індексом функціональності енергетичної архітектури.

На рис. 1 відображено порівняння рейтингових показників США та країн Каспійського регіону за 2009 i 2017 pp.

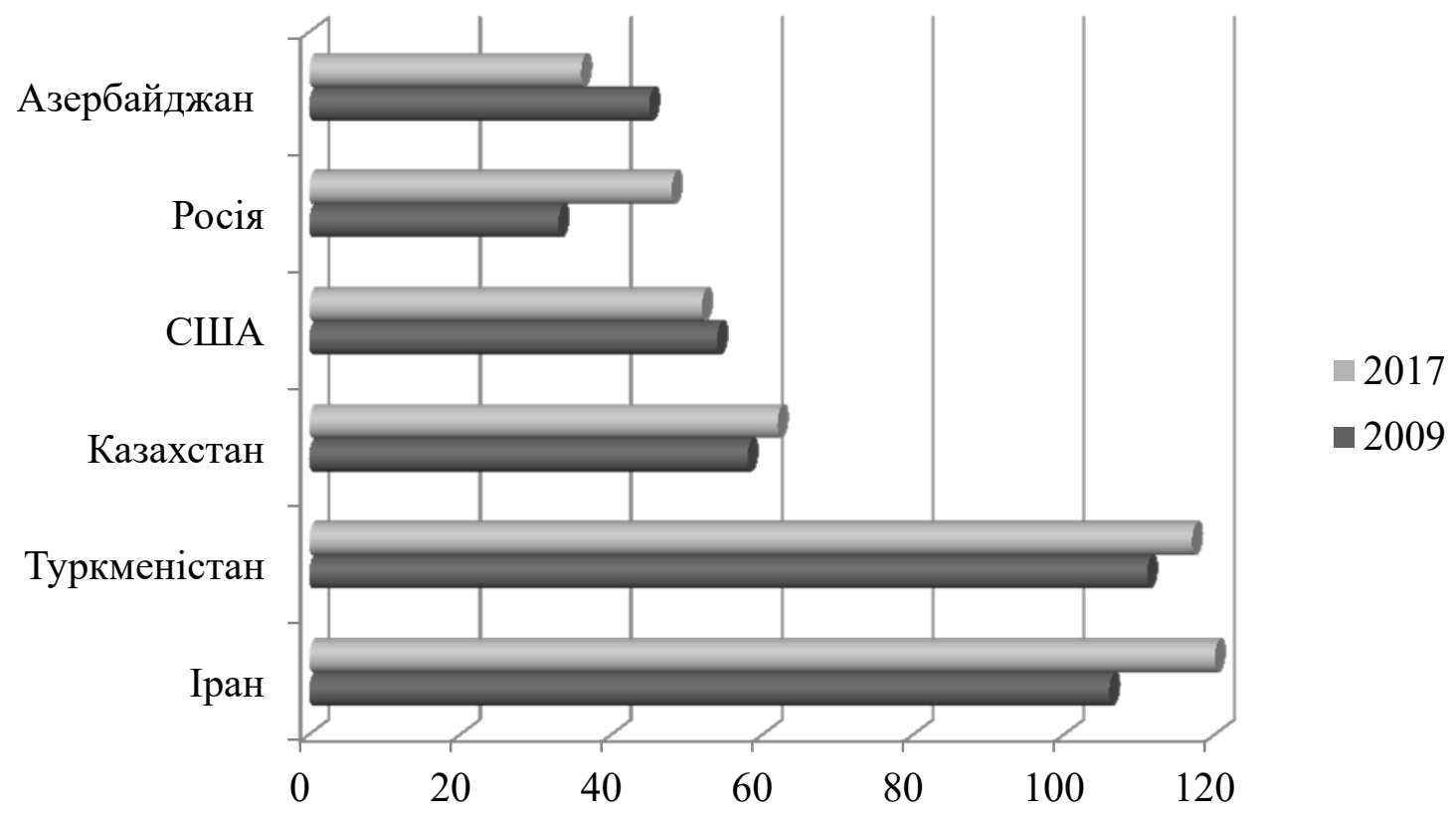

\section{Рис. 1. Рейтингові позиції США та краӥн Каспійського регіону за Індексом функціональності енергетичної архітектури 2017 р.}

Аналіз статистичних даних за 2017-й рік показав, що порівняно з 2009-м роком такі країни, як Іран, Казахстан, Росія і Туркменістан знизили свої позиції в рейтингу за Індексом функціональності енергетичної архітектури $(-14,-4,-15$ і -6 відповідно) [31]. Натомість спостерігаємо приріст в показниках Азербайджану (+9) і США (+2). Показники Росії значно знижує встановлена монополія на видобуток і транспортування енергетичних ресурсів, що порушує принцип доступу до джерел енергії, а також становить загрозу енергетичній безпеці. Приріст в показниках США відбувається завдяки розвитку нетрадиційних джерел енергії як основи екологічної стійкості, забезпечення енергетичної безпеки і сталого економічного розвитку країни. Враховуючи більш вигідні позиції Азербайджану, Казахстану і Туркменістану в рейтингу, вони є основними країнами Каспійського регіону, з якими прагнуть розвивати співробітництво позарегіональні країни. 
Проведений теоретичний аналіз означеної проблеми дослідження показав, що на сучасному етапі серед країн Каспійського регіону існують відмінності в енергетичній політиці цих країн. Зокрема, Росія прагне не допустити переважання впливу третіх країн у регіоні, збільшити експорт нафти та газу з регіону, розширити свою участь у нафтогазових проектах Каспії. Враховуючи значні запаси вуглеводних ресурсів в Перській затоці, для Ірану освоєння ресурсів Каспію не $\epsilon$ важливим завданням, однак ця країна більшою мірою орієнтована на співпрацю з Росією на противагу США та країнам ЄС. Азербайджан прагне переважно до формування альтернативних маршрутів експорту енергоресурсів. Туркменістан, враховуючи внутрішньоконтинентальне географічне положення, поки що обмежений у проведенні незалежної енергетичної політики. Казахстан прагне до паралельного розвитку енергетичного співробітництва одночасно з Росією, США та ЄС.

Інтерес Росії до Каспійського регіону полягає у забезпеченні стабільного соціальноекономічного розвитку і безпеки на півдні Каспійського моря. Важливе значення Каспійського регіону для Росії відображає Концепція зовнішньої політики РФ, яка була затверджена в лютому 2013-го року. Така ситуація спрямовує увагу російського керівництва до проблем регіону і створює умови для подальшого розвитку багатостороннього переговорного процесу між прикаспійськими країнами, в тому числі, і з питання міжнародно-правового статусу Каспійського моря.

Зовнішньополітична діяльність США в Каспійському регіоні полягає у розширенні співробітництва у сфері енергетики з Азербайджаном, Казахстаном i Туркменістаном, зокрема шляхом будівництва трубопровідної системи постачання енергоносіїв. Причому, враховуючи превалювання геополітичних чинників в регіоні над економічними, відбувається політизація сфери транспортування енергоресурсів Каспію. Відтак, проекти розбудови трубопроводів часто не можуть реалізуватися саме через протистояння глобальних геополітичних акторів (ЄС, Росії, США та Китаю).

Висновки. На сьогодні Каспійський регіон відіграє важливу роль. Вигідне геополітичне положення перетворює цей регіон у зону стратегічних інтересів багатьох великих світових акторів, зокрема Російської Федерації і Сполучених Штатів Америки. У зв'язку з цим Каспійський регіон залишається для Росії та США пріоритетним напрямом зовнішньої політики.

Енергетична політика США в Каспійському регіоні спрямована на розширення комерційних можливостей для американського бізнесу і ослаблення зв'язків країн регіону з Росією. Водночас енергетична політика США передбачає зниження рівня залежності від постачань енергоресурсів із Близького Сходу, зниження іранського впливу на енергетичний сектор прибережних країн Каспію, а також недопущення появи проектів розробки каспійських родовищ за участю Росії.

Наразі ситуація в Каспійському регіоні продовжує загострюватися. По-перше, боротьбою за контроль над потенційним джерелом енергетичних ресурсів як країн регіону, так і поза регіональних країн; по-друге, знаходженням регіону в центрі лінії геополітичного розлому пострадянського простору і на перетині важливих транспортних комунікацій; по-третє, великим конфліктним потенціалом як на Північному, так і на Південному Кавказі. Політика Росії і США спрямована на вигідне співробітництво з країнами Каспійського регіону щодо розробки i транспортування енергетичних ресурсів регіону до країн-споживачів. Окрім цього, на сучасному етапі відбувається активний пошук і будівництво нових шляхів транспортування енергетичної сировини. I Росія, і США $є$ основними суперниками щодо побудови ефективних шляхів транспортування енергоносіїв з метою зменшити вплив одна одної на території Каспію.

\section{Бібліографічний список:}

1. Бжезинский 3. Выбор. Мировое господство или глобальное лидерство : монография. Москва : Междунар. отношения, 2004. 288 с.

2. Голубой поток. URL: http://www.gazprom.ru/about/production/projects/pipelines/active/blue-stream/

3. Грозин А., Корнеев А., Ершов Ю., Симония Н., Симонов К. «Защита Лугара»: американская администрация бросает очередной «энергетический вызов» России. Нефть России. Москва, 2008. № 5. C. $18-25$. 2006.

4. Губайдуллин А. Газ в Европе: есть ли альтернатива. Россия в глобальной политике. Москва, №1.

5. Джиоев А.Т. Тенденции и перспективы добычи и транспортировки энергоресурсов шельфа Каспийского моря. URL: https://cyberleninka.ru/article/v/tendentsii-i-perspektivy-dobychi-i-transportirovkienergoresursov-shelfa-kaspiyskogo-morya

6. Долгушев Д. В. Конфликт энергетических интересов России и США в Центральной Азии и Каспийском регионе. Вестник Томского государственного университета. Томск, 2011. №4. С. 90-97. 
7. Енергетична безпека партнерів США в Свразії залежить від стабільності Каспію - колишній посол

США URL: https://ukrainian.voanews.com/a/caspian-becoming-new-center-144935245/918539.html

8. Жукова И. С. Энергетическая дипломатия и геополитика как составной элемент международного енергетического права. URL: http://vestnik.osu.ru/ 2010_3/11.pdf

9. Зеркалов Д.В. Политическая безопасность : монография. Киев : Основа, 2012. 1067 с.

10. Лукьянов C., Перфилов М. Война маршрутов. URL: http://www.nefte.ru/oilworld/kaspiy23.htm

11. Меджид Ф. США и Азербайджан провели консультации по вопросам безопасности. 25 июня 2011.

URL: http://www.kavkaz-uzel.ru/articles/ 187865/

12. На саммите в Астрахани не решили главную проблему Каспия.

URL: http://www.bbc.co.uk/russian/international/2014/09/140929_caspian_sea_summit

13. Нафтопровід Баку-Тбілісі-Джейхан відкрито.

URL: https://www.bbc.com/ukrainian/news/story/2006/07/060713_aku_tbilisi_oil_sp.shtml

14. Назарбаєв Н: Досягнута домовленість про участь Казахстану в проекті «Бургас-Александруполіс».

URL: https://www.rbc.ua/ukr/news/n_nazarbaev_dostignuta_dogovorennost_ob_uchastii_kazahstana_v_proekte_

burgas_aleksandrupolis__1198153148

15. «Південний потік» перейменують у «Сербський потік».

URL: https://ukr.lb.ua/world/2018/01/29/388471_pivdenniy_potik_pereymenuyut.html

16. Ричард Морнингстар прибыл в Баку. URL: http://echo.az/article.php?aid=25212

17. Салыгин В., Сафарян А. Современные международные экономические отношения в Каспийском

регионе : монография. Москва : МГИМО (У), 2005. 344 с.

18. США готують санкції проти компаній-учасниць «Північного потоку-2».

URL: https://www.radiosvoboda.org/a/news/29268295.html

19. США почали регулярно постачати зріджений газ в Європу. URL: https://biz.nv.ua/ukr/markets/

ssha-pochali-reguljarno-postachati-zridzhenij-gaz-v-jevropu-1298861.html

20. Текеев А. Политические технологии в энергетической дипломатии.

URL: http://www.observer.materik. ru/observer/N10_2013/024_037.pdf

21. Терентьев С.А. Нефть : монография. Москва : Книжный Клуб Книговек, 2011. 416 с.

22. У Сврокомісії відмовилися підтримувати «Північний потік-2».

URL: https://dt.ua/ECONOMICS/u-yevrokomisiyi-vidmovilisya-pidtrimuvati-pivnichniy-potik-2-274449_html

23. Уткин А. И. Американская стратегия для XXI века : монография. Москва : Логос, 2000. 216 с.

24. Черницына С.Ю. Роль энергетической дипломатии в формировании внешней политики России на современном этапе (2000-2014) : дисс. ...канд. истор. наук : 07.00.15 / Моск. гос. ин-тут междунар. отношений (ун-тет) МИД Российской Федерации. Москва, 2015. 175 с.

25. Чумалов М. Каспийская нефть и межнациональные отношения : монография. Москва : ЦИМО, 2000. $560 \mathrm{c}$.

26. Южный Кавказ: тенденции и проблемы развития (1992-2008 гг.) / под ред. В.А. Гусейнова. Москва : 2008. 392 c.

27. Energy and Security: Toward a New Foreign Policy Strategy : monograph. Washington - Baltimore:

Woodrow Wilson Center Press, Johns Hopkins University Press, 2005. 604 p.

28. Letter before 19 the World Petroleum Congress in Spain 2008. World Petroleum Council.

URL: http://www.world-petroleum.org/index.php?/Congresses/19th-wpc.html

29. Monbiot G. A discreet deal in the pipeline. The Guardian. 2001.

URL: https://www.theguardian.com/business/2001/feb/15/oil.georgemonbiot

30. TAP project scheduleю URL: http://www.tap-ag.com/the-pipeline/project-timeline

31. The Global Energy Architecture Performance Index Report 2017. The World Economic Forum. Geneva,

2017. - 32 pp. - URL: http://www3.weforum.org/docs/WEF_Energy_Architecture_Performance_Index_2017.pdf

32. U.S. Interests in Central Asia: Policy Priorities and Military Roles. RAND. Project Air Force. Prepared for the United States Air Force. 2005. P. 81.

\section{References:}

1. Bzhezinskiy Z. Vyibor. Mirovoe gospodstvo ili globalnoe liderstvo : monografiya. Moskva : Mezhdunar. otnosheniya, 2004. 288 s.

2. Goluboy potok. URL: http:/www.gazprom.ru/about/production/projects/pipelines/active/blue-stream/

3. Grozin A., Korneev A., Ershov Yu., Simoniya N., Simonov K. «Zaschita Lugara»: amerikanskaya administratsiya brosaet ocherednoy «energeticheskiy vyizov» Rossii. Neft Rossii. Moskva, 2008. № 5. S. 18-25.

4. Gubaydullin A. Gaz v Evrope: est li alternativa. Rossiya v globalnoy politike. Moskva, №1. 2006.

5. Dzhioev A.T. Tendentsii i perspektivyi dobyichi i transportirovki energoresursov shelfa Kaspiyskogo morya. URL: https://cyberleninka.ru/article/v/tendentsii-i-perspektivy-dobychi-i-transportirovki-energoresursov-shelfakaspiyskogo-morya

6. Dolgushev D. V. Konflikt energeticheskih interesov Rossii i SShA v Tsentralnoy Azii i Kaspiyskom regione. Vestnik Tomskogo gosudarstvennogo universiteta. Tomsk, 2011. №4. C. 90. 
7. Enerhetychna bezpeka partneriv SShA v Yevrazii zalezhyt vid stabilnosti Kaspiiu - kolyshnii posol SShA. URL: https://ukrainian.voanews.com/a/caspian-becoming-new-center-144935245/918539.html

8. Zhukova I. S. Energeticheskaya diplomatiya i geopolitika kak sostavnoy element mezhdunarodnogo energeticheskogo prava. URL: http://vestnik.osu.ru/2010_3/11.pdf

9. Zerkalov D.V. Politicheskaya bezopasnost : monografiya. Kiev : Osnova, 2012. 1067 s.

10. Lukyanov S., Perfilov M. Voyna marshrutov. URL: http://www.nefte.ru/oilworld/kaspiy23.htm

11. Medzhid F. SShA i Azerbaydzhan proveli konsultatsii po voprosam bezopasnosti. 25 iyunya 2011. URL: http://www.kavkaz-uzel.ru/articles/ 187865/

12. Na sammite $v$ Astrahani ne reshili glavnuyu problemu Kaspiya.

URL: http://www.bbc.co.uk/russian/international/2014/09/140929_c

13. Naftoprovid Baku-Tbilisi-Dzheikhan vidkryto. URL:

https://www.bbc.com/ukrainian/news/story/2006/07/060713_aku_tbilisi_oil_sp.shtml

14. Nazarbaiev N: Dosiahnuta domovlenist pro uchast Kazak̄hstanu v proekti «Burhas-Aleksandrupolis». URL: https://www.rbc.ua/ukr/news/n_nazarbaev_dostignuta_dogovorennost_ob_uchastii_kazahstana_v_proekte_ burgas_aleksandrupolis_1198153148

15. «Pivdennyi potik» pereimenuiut $\mathrm{u}$ «Serbskyi potik».

URL: https://ukr.lb.ua/world/2018/01/29/388471 pivdenniy potik pereymenuyut.html

16. Richard Morningstar pribyil v Baku. URL: http://echo.az/article.php?aid=25212

17. Salyigin V., Safaryan A. Sovremennyie mezhdunarodnyie ekonomicheskie otnosheniya v Kaspiyskom regione : monografiya. Moskva : MGIMO (U), 2005. 344 s.

18. SShA hotuiut sanktsii proty kompanii-uchasnyts «Pivnichnoho potoku-2».

URL: https://www.radiosvoboda.org/a/news/29268295.html

19. SShA pochaly rehuliarno postachaty zridzhenyi haz v Yevropu. URL: https://biz.nv.ua/ukr/markets/ ssha-pochali-reguljarno-postachati-zridzhenij-gaz-v-jevropu-1298861.html

20. Tekeev A. Politicheskie tehnologii v energeticheskoy diplomatii. URL: http://www.observer.materik. ru/ observer/N10_2013/024_037.pdf

21. Terentev S.A. Neft : monografiya. Moskva : Knizhnyiy Klub Knigovek, 2011. 416 s.

22. U Yevrokomisii vidmovylysia pidtrymuvaty «Pivnichnyi potik-2». URL: https:/dt.ua/ECONOMICS/ u-yevrokomisiyi-vidmovilisya-pidtrimuvati-pivnichniy-potik-2-274449_html

23. Utkin A. I. Amerikanskaya strategiya dlya XXI veka : monografiya. Moskva : Logos, 2000. $216 \mathrm{s.}$

24. Chernitsyina S.Yu. Rol energeticheskoy diplomatii v formirovanii vneshney politiki Rossii na sovremennom etape (2000-2014) : diss. ...kand. istor. nauk : 07.00.15 / Mosk. gos. in-tut mezhdunar. otnosheniy (un-tet) MID Rossiyskoy Federatsii. Moskva, 2015. 175 s.

25. Chumalov M. Kaspiyskaya neft i mezhnatsionalnyie otnosheniya : monografiya. Moskva : TsIMO, 2000. $560 \mathrm{~s}$.

26. Yuzhnyiy Kavkaz: tendentsii i problemyi razvitiya (1992-2008 gg.) / pod red. V.A. Guseynova. Moskva : 2008.392 c.

27. Energy and Security: Toward a New Foreign Policy Strategy : monograph. Washington - Baltimore: Woodrow Wilson Center Press, Johns Hopkins University Press, 2005. 604 p.

28. Letter before 19 the World Petroleum Congress in Spain 2008. World Petroleum Council.

URL: http://www.world-petroleum.org/index.php?/Congresses/19th-wpc.html

29. Monbiot G. A discreet deal in the pipeline. The Guardian. 2001.

URL: https://www.theguardian.com/business/2001/feb/15/oil.georgemonbiot

30. TAP project scheduleю URL: http://www.tap-ag.com/the-pipeline/project-timeline

31. The Global Energy Architecture Performance Index Report 2017. The World Economic Forum. Geneva, 2017. - 32 pp. - URL: http://www3.weforum.org/docs/WEF_Energy_Architecture_Performance_Index_2017.pdf

32. U.S. Interests in Central Asia: Policy Priorities and Military Roles. RAND. Project Air Force. Prepared for the United States Air Force. 2005. P. 81.

\section{Shikhalili Javid The Ratio of Russia's Regional Policy and the US in the Energy Dimension}

The article analyzes the goals and objectives of the diplomacy of Russia and the United States in the Caspian region. The author proves the problem of transit in Russian and American energy diplomacy in the region, examines the interstate relations between Russia and the United States with the countries of the region in the field of energy. The Caspian region has become a new center of gravity of the interests of the countries of the West and the East, and it attracts more and more attention not only as an energy exporting region, but also as an important transit hub. It is the energy factor that has become a prerequisite for political, legal and economic changes in the Caspian region. Given the geostrategic position, political, economic, environmental and other factors, the Caspian region is important for the Russian Federation, at the same time in terms of ensuring national security of military-political and socio-economic nature. The Russian Federation is trying to play a key role in the region, taking into account both the energy and 
geopolitical factors. In order to secure its own national interests, Russia seeks to preserve its military and political influence in the region and to exclude access of Western forces to the territory of the Caspian Sea. Significant geopolitical interests in the Caspian region are the United States of America. The United States is trying to pursue an energy policy in the region and actively influence the process of exploiting the Caspian Sea's energy resources. To this end, we adopted a new strategy of American energy policy, which was to push Russia out of the Caspian region. In this way, US energy diplomacy has created a new geopolitical situation in relations with Russia. The purpose of the article is to analyze the ratio of regional policy of Russia and the US in the energy dimension. It is stated that the regional strategy of Russia is aimed at the political isolation of the region, which was successfully implemented during the first decades. Its methods are creating zones of controlled instability, delaying the territorial delineation and creating contradictions in the relations of the Caspian states, military domination. The research methods include geostrategic analysis of the position of the countries of the region in the context of the energy goals of the policy of major countries - the United States and the Russian Federation. Used methods of comparative and comparative-historical analysis, which allowed to determine the preconditions for the formation of regional policy of Russia and the United States in the energy dimension. The author concludes that stable socio-economic development and security in the south of the Caspian Sea can only be achieved if the mechanisms of international cooperation are sought, the result of which may be the signing of a multilateral agreement on the international legal status of the Caspian Sea.

Key words: energy sphere, Caspian region, Caspian Sea, international legal status, Caspian states, regional policy. 